\title{
PERANCANGAN SISTEM ADMINISTRASI PEMESANAN TIKET BUS PARIWISATA PT FITRI TRANS ABADI
}

\author{
Nurkholis $^{1}$, Thomas Afrizal ${ }^{2}$, Asri Budiarto ${ }^{3}$ \\ Informatika $^{1}$, Informatika ${ }^{2}$, Teknik Arsitektur ${ }^{3}$ \\ ${ }^{123}$ Teknik dan Ilmu Komputer \\ ${ }^{123}$ Universitas Indraprasta PGRI \\ kholischuis@gmail.com ${ }^{1}$, thomztaurus.it@gmail.com², \\ budiartoasri01@gmail.com ${ }^{3}$
}

\begin{abstract}
Abstrak: Dalam melakukan kegiatannya perusahaan menginginkan kemajuan untuk perusahaan, salah satunya dengan peningkatakan kinerja perusahaan melaui efisiensi dan efektivitas kerja. Selain itu perusahaan juga ingin meminimalisir kekurangan pada kegiatan bisnis mereka dengan memperbarui atau memperbaiki sistem yang ada. Pada kajian ini, perancangan sistem administrasi pemesanan tiket bus pariwisata PT Fitri Trans Abadi dapat relevan dengan sistem yang bertujuan untuk mengatasi masalah administrasi perusahaan. Dalam penelitian ini, peneliti menggunakan metode research and development $(R$ and $D)$. Dalam merancang sistem administrasi ini peneliti menggunakan alat bantu perancangan sistem, yaitu Diagram Alir Data (DAD). Peneliti menggunakan bahasa pemrograman Java dan database MySQL dalam merancang program aplikasi sistem administrasi pemesanan tiket bus pariwisata. Hasil dari penelitian ini adalah sistem administrasi pemesanan tiket bus pariwisata yang dapat membantu petugas dalam mengelola data penumpang dan pembayaran serta operasional bus secara lebih baik. Sistem administrasi pemesanan tiket bus pariwisata ini juga dapat mempermudah perhitungan pembayaran secara akurat.
\end{abstract}

Kata kunci: Sistem, administrasi, pemesanan, Java, MySQL

\begin{abstract}
In conducting its activities the company wants progress for the company, one of which is by improving the company's performance through efficiency and effectiveness of work. In addition, companies also want to minimize deficiencies in their business activities by updating or improving existing systems. In this study, the design of tourism bus ticket booking administration system of PT Fitri Trans Abadi can be relevant to the system aimed at addressing the company's administrative problems. In this study, researchers used research and development $(R$ and $D)$ methods. In designing this administration system, researchers used a system design tool, namely Data Flow Diagram (DFD). Researchers used the Java programming language and MySQL database in designing the tourism bus ticket booking administration system application program. The result of this research is a tourism bus ticket booking administration system that can help officers in managing passenger data and payments and bus operations better. This tourism bus ticket booking administration system can also facilitate accurate payment calculation.
\end{abstract}

Keywords: Systems, Administration, Booking, Java, MySQL

\section{PENDAhUluan}

Penggunaan tools dan teknologi pada saat sekarang bukan hanya sekedar memberikan kemudahan dan kenyamanan kerja tetapi juga berguna dalam peningkatan efisiensi kerja. Efisiensi inilah yang kemudian akan

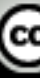

Ciptaan disebarluaskan di bawah Lisensi Creative Commons Atribusi 4.0 Internasional. 
mempengaruhi kinerja perusahaan. PT Fitri Trans Abadi merupakan sebuah perusahaan yang bergerak di bidang jasa transportasi dan memasarkan jasa antar dalam kota atau luar kota ke berbagai wilayah di Indonesia. Dalam proses pemesanan bus pariwisata digunakan berbagai alat-alat penunjang seperti surat reservasi, bukti pembayaran, surat jalan kendaraan dan lain-lain. Salah satu kendala yang dialami oleh PT Fitri Trans Abadi adalah dalam pengolahan data pemesanan kendaraan. Pada PT Fitri Trans Abadi, sistem pengolahan data pemesanan kendaraannya masih sangatlah sederhana. Pengolahan data yang digunakan masih menggunakan cara manual yaitu hanya dicatat dibuku setiap ada pemesanan bus pariwisata, lalu tiap pemesanan pemesan hanya diberi bukti pemesanan yang diketik manual melalui Microsoft Word, dan laporan bus pariwisata yang sudah dipesan direkap secara sederhana melalui Aplikasi Microsoft Excel, dengan merekap data seperti ini mempunyai beberapa kelemahan yang dapat menghambat untuk mendapatkan informasi yang cepat, tepat dan akurat. Kelemahan tersebut antara lain yaitu kesalahan dalam pemesanan bus yang sudah terbooking atau belum, kesulitan mencari data yang diinginkan, data tidak tergabung dalam satu daftar dan tidak dapat berinteraksi dengan database.

\section{METODE DAN MATERI}

Perancangan merupakan sebuah proses untuk mendefinisikan suatu yang akan dikerjakan dengan menggunakan teknik yang bervariasi. Didalamnya melibatkan deskripsi mengenai arstitektur serta detail mengenai komponen dan juga keterbatasan yang akan dialami dalam proses pengerjaanya [1]. Perancangan sistem adalah sebuah proses yang menentukan bagaimana suatu sistem akan menyelesaikan apa yang mesti diselesaikan. Tahap ini dapat berupa penggambaran, perencanaan dan pembuatan sketsa atau pengaturan dari beberapa element yang terpisah ke dalam satu kesatuan yang utuh dan berfungsi [2]. Untuk mendukung sistem administrasi pemesanan tiket bus pariwisata yang efektif perlu di rancang suatu sistem basis data operasional java desktop yang lebih mudah digunakan, sehingga akan membantu administrator dalam mengolah data-data yang dibutuhkan menjadi lebih akurat, efisien dan hemat waktu.

Metode penelitian yang akan digunakan oleh peneliti adalah metode Research and Development. Definisi metode research and development menurut [3] yang terdapat dalam jurnal yang berjudul "Konsep Penelitian R\&D dalam Bidang Pendidikan" menjelaskan bahwa" Research and Development $(R \& D)$ adalah metode penelitian yang digunakan untuk menghasilkan produk tertentu dan menguji keefektifan metode tersebut.

Metode pengumpulan data yang dilakukan untuk mendapatkan data-data serta informasi agar mendukung penyempurnaan hasil dari penelitian ini antara lain:

1. Observasi

Melakukan pengamatan langsung dengan cara melihat dan mengamati proses pemesanan tiket bus pariwisata pada PT Fitri Trans Abadi.

2. Metode Wawancara

Wawancara dilakukan di PT Fitri Trans Abadi kepada narasumber yang terkait dengan informasi operasional pemesanan bus pariwisata untuk memperoleh data yang jelas dan akurat

3. Studi Pustaka

Yakni metode pengumpulan data dengan cara mempelajari beberapa buku, sarana perpustakaan, dan catatan-catatan kuliah yang berhubungan dengan yang diajukan.

\section{PEMbahaSAN DAN HASIL}

Sistem yang baru diusulkan merupakan komputerasi sistem lama atau sistem berjalan, dimana cara kerja atau prosedur sistem yang baru tidak jauh berbeda. Perubahan dari sistem yang lama ke sistem yang baru diharapkan akan dapat membantu dan mengatasi permasalahan yang timbul pada sistem yang lama. Berikut ini adalah dekomposisi fungsi untuk sistem yang diusulkan : 


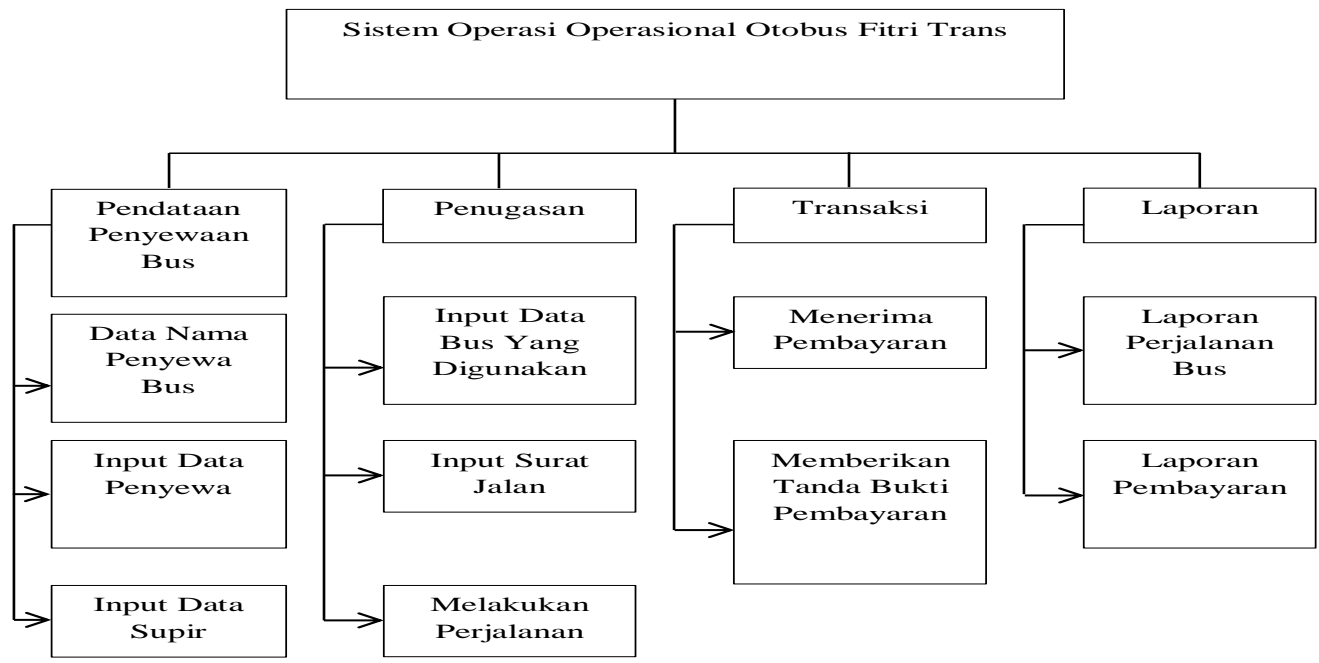

Gambar 1. Dekomposisi Fungsi

DFD adalah suatu network yang menggambarkan suatu sistem komputerisasi, manualisasi, atau gabungan dari keduanya, yang penggambarnya disusun dalam bentuk kumpulan komponen sistem yang saling berhubungan sesuai dengan aturan mainnya [4]. Berikut adalah rancangan diagram alir data :

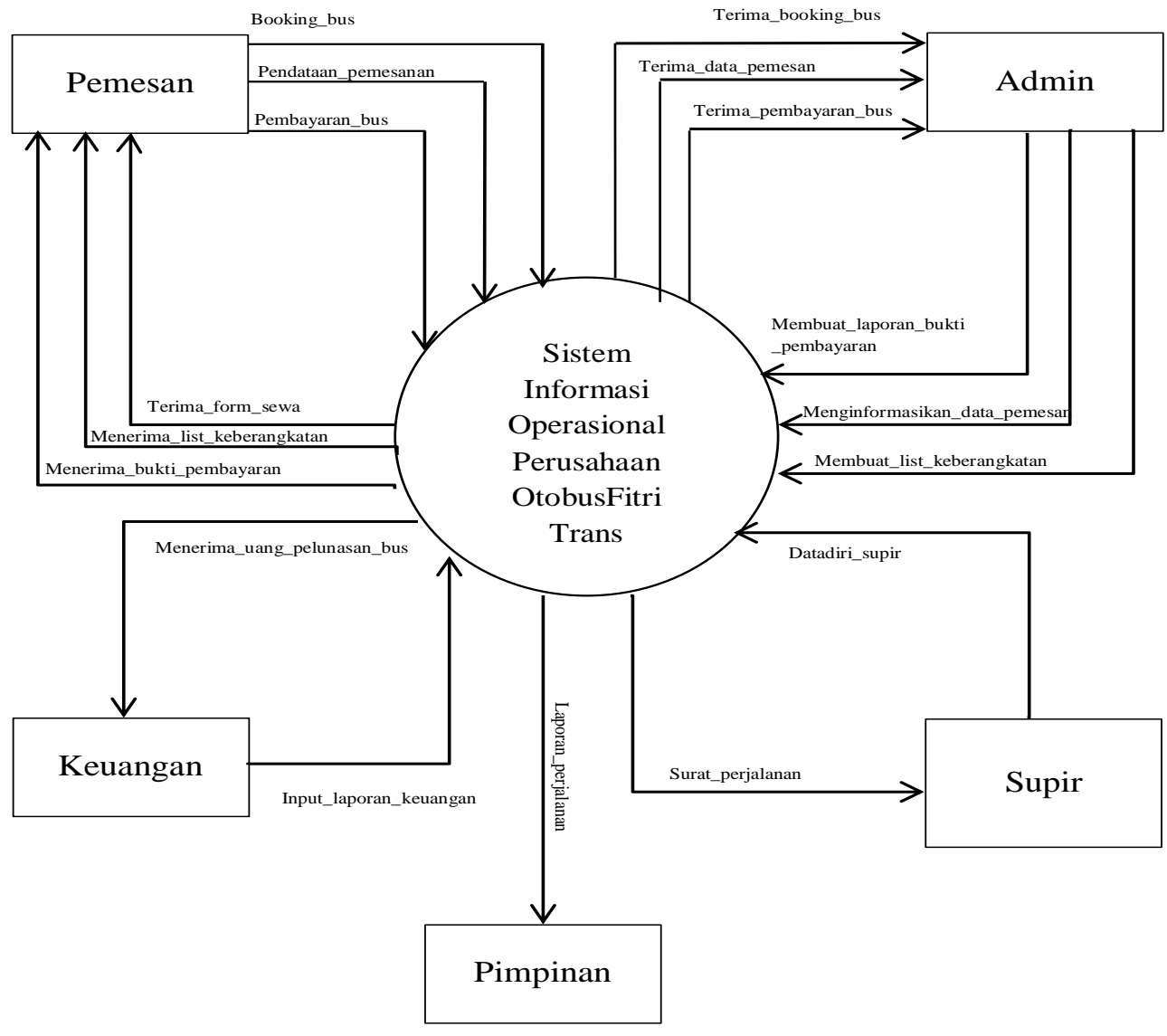

Gambar 2. Diagram Alir Data 
Dalam perancangan sistem administrasi pemesanan tiket bus pariwisata di PT Fitri Trans Abadi menggunakan penyimpanan basis data. Database adalah suatu kumpulan atau susunan data operasional lengkap dari suatu organisasi yang diorganisir atau dikelola dan disimpan secara terintegritasi dengan menggunakan metode tertentu menggunakan komputer sehingga mampu menyediakan informasi yang optimal yang diperlukan pemakainya. MySQL adalah database open source paling populer di dunia. Perancangan basis data bertujuan untuk mengetahui file-file basis data yang digunakan dalam perancangan sistem ini, sekaligus mengetahui hubungan antara file dan basis data tersebut. Perancangan basis data ini meliputi normalisasi, ERD, dan spesifikasi file. ERD (Entity Relationship Diagram) adalah suatu model jaringan yang menggunakan susunan data yang disimpan dalam sistem secara abstrak [5].

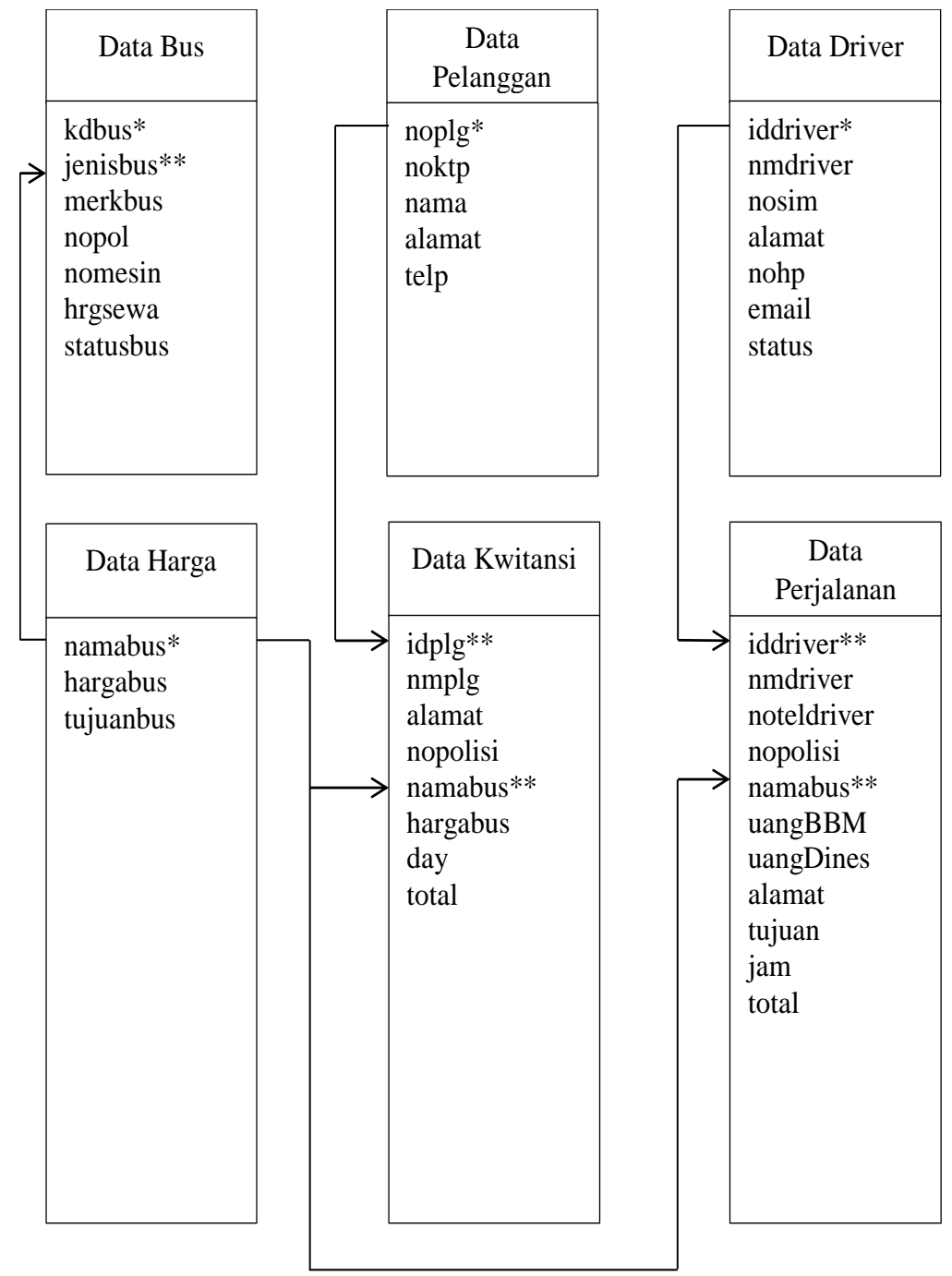

Gambar 3. Normalisasi Bentuk 2NF 


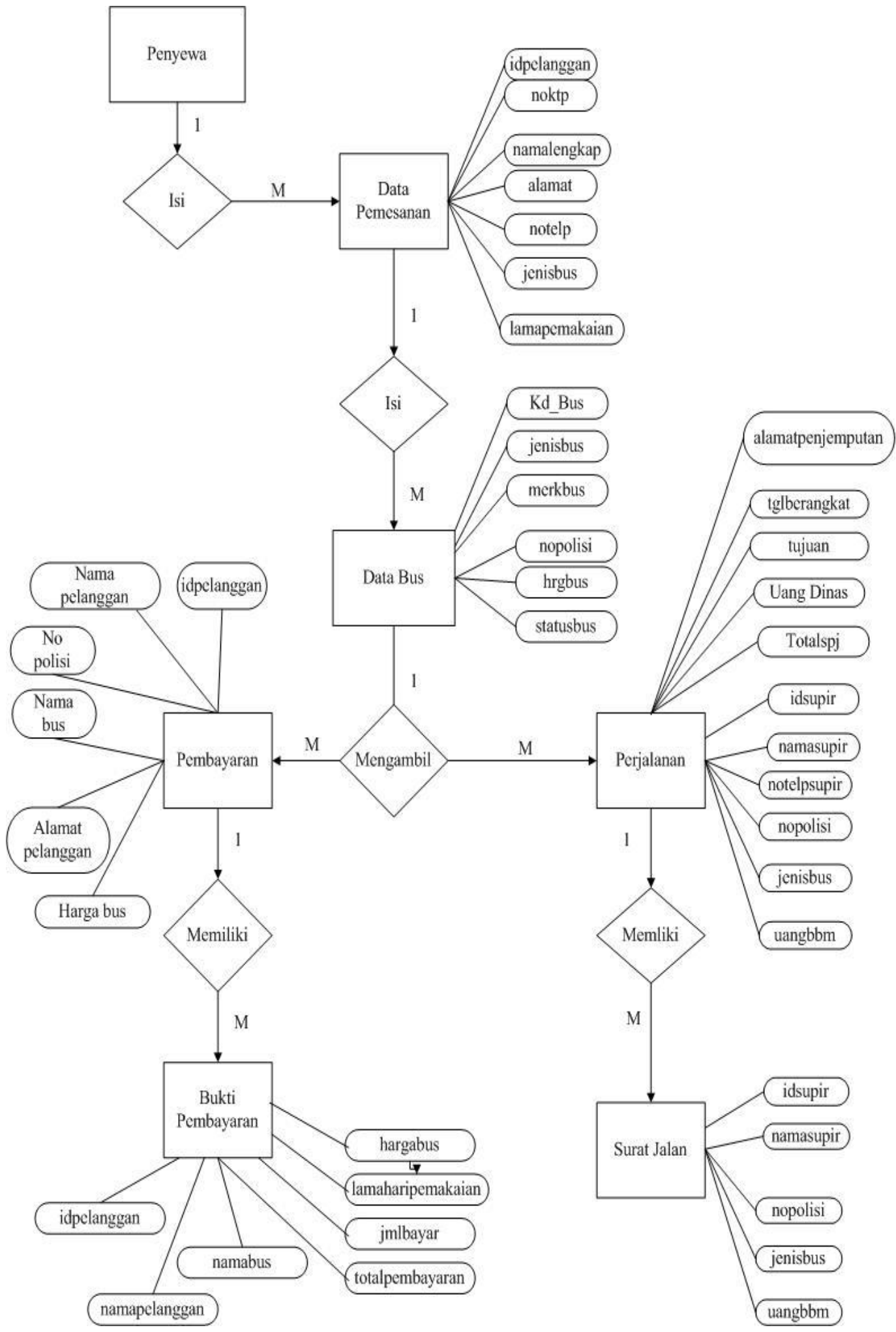

Gambar 4. Entity Relationship Diagram 


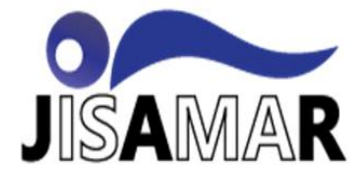

Journal of Information System, Applied, Management, Accounting and Research.

http://journal.stmikjayakarta.ac.id/index.php/jisamar, jisamar@stmikjayakarta.ac.id ,jisamar2017@gmail.com e-ISSN: 2598-8719 (Online), p-ISSN: 2598-800 ( Printed), Vol. 5 No.1 Februari 2021

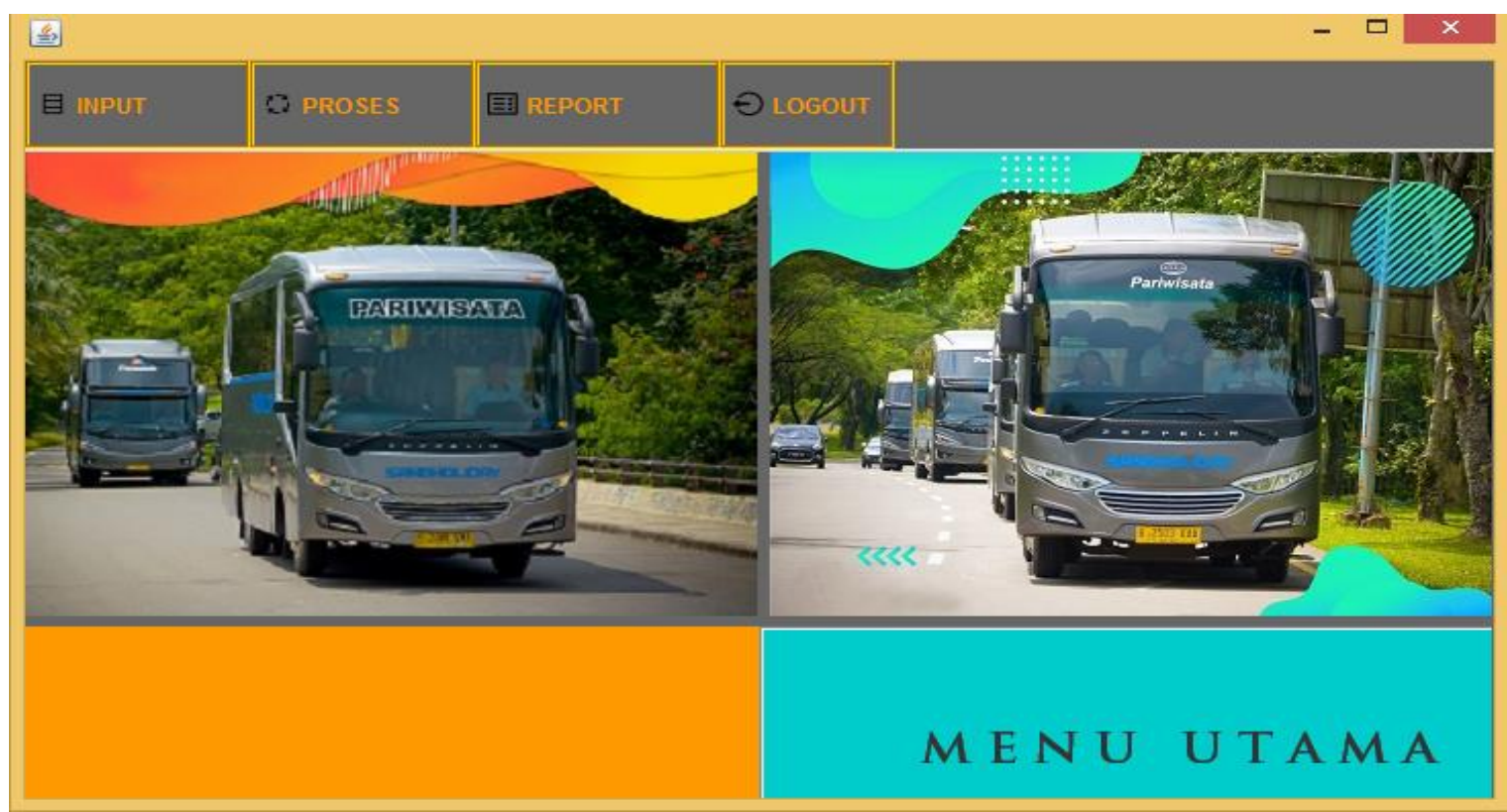

Gambar 5. Tampilan Layar Menu Utama

Pada tampilan menu utama merupakan rancangan tampilan form menu saat setelah berhasil menyelesaikan login. Form ini memiliki beberapa tombol yang terdiri dari tombol data tim untuk masuk ke form data tim. Tombol jadwal untuk masuk ke form jadwal, tombol bayar untuk masuk ke form pembayaran dan pelunasan, tombol laporan untuk memasuki tampilan cetak laporan dan tombol logout untuk kembali ke tampilan login.

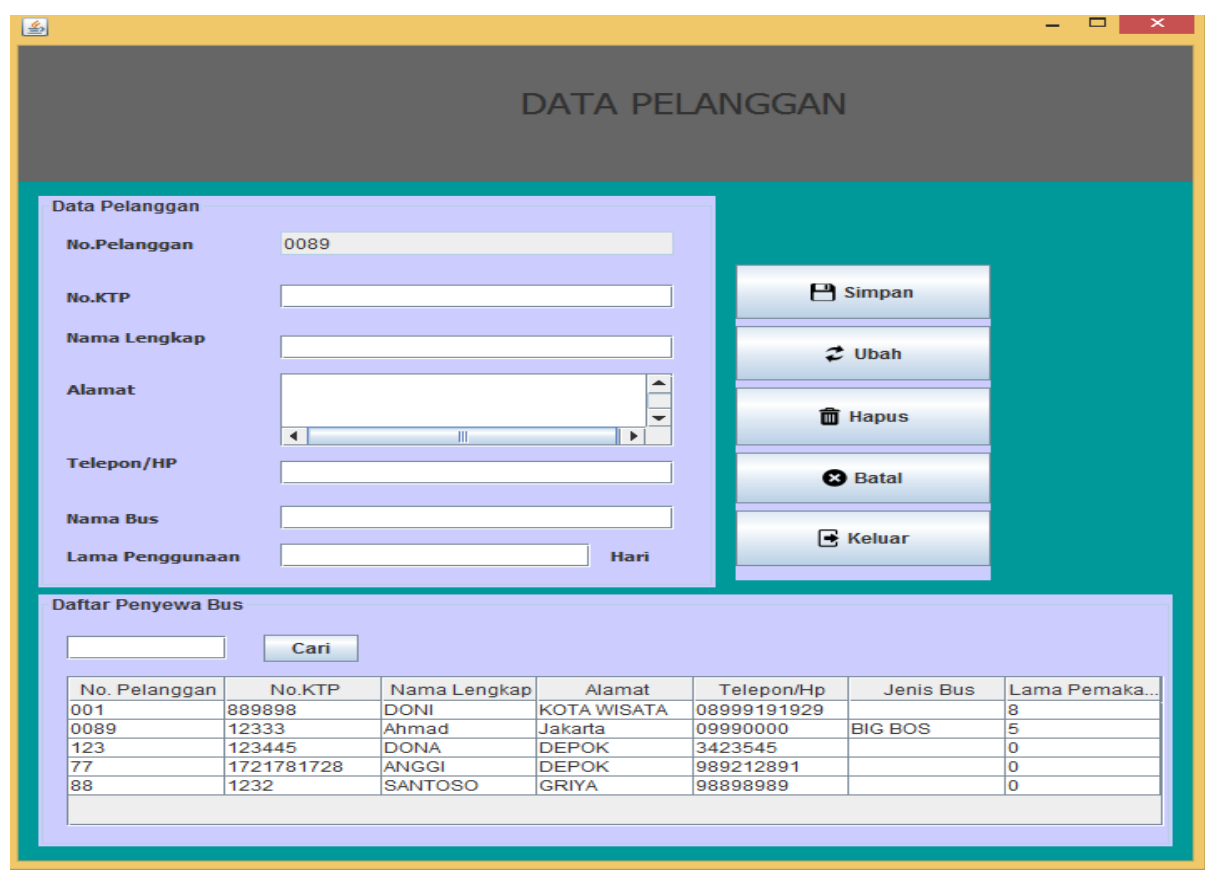

Gambar 6. Tampilan Format Masukan Data Pelanggan

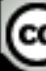

Ciptaan disebarluaskan di bawah Lisensi Creative Commons Atribusi 4.0 Internasional. 
Form ini berisikan mengenai data pelanggan, untuk memasukkan data pelanggan baru, menyimpan data pelanggan yang telah di-input pengguna bus, mengubah data yang telah di-input pengguna bus, menghapus data yang telah diinput pengguna dan pencarian data yang akan di cari oleh pengguna bus. Serta tombol kembali untuk kembali ke dalam tampilan menu utama.

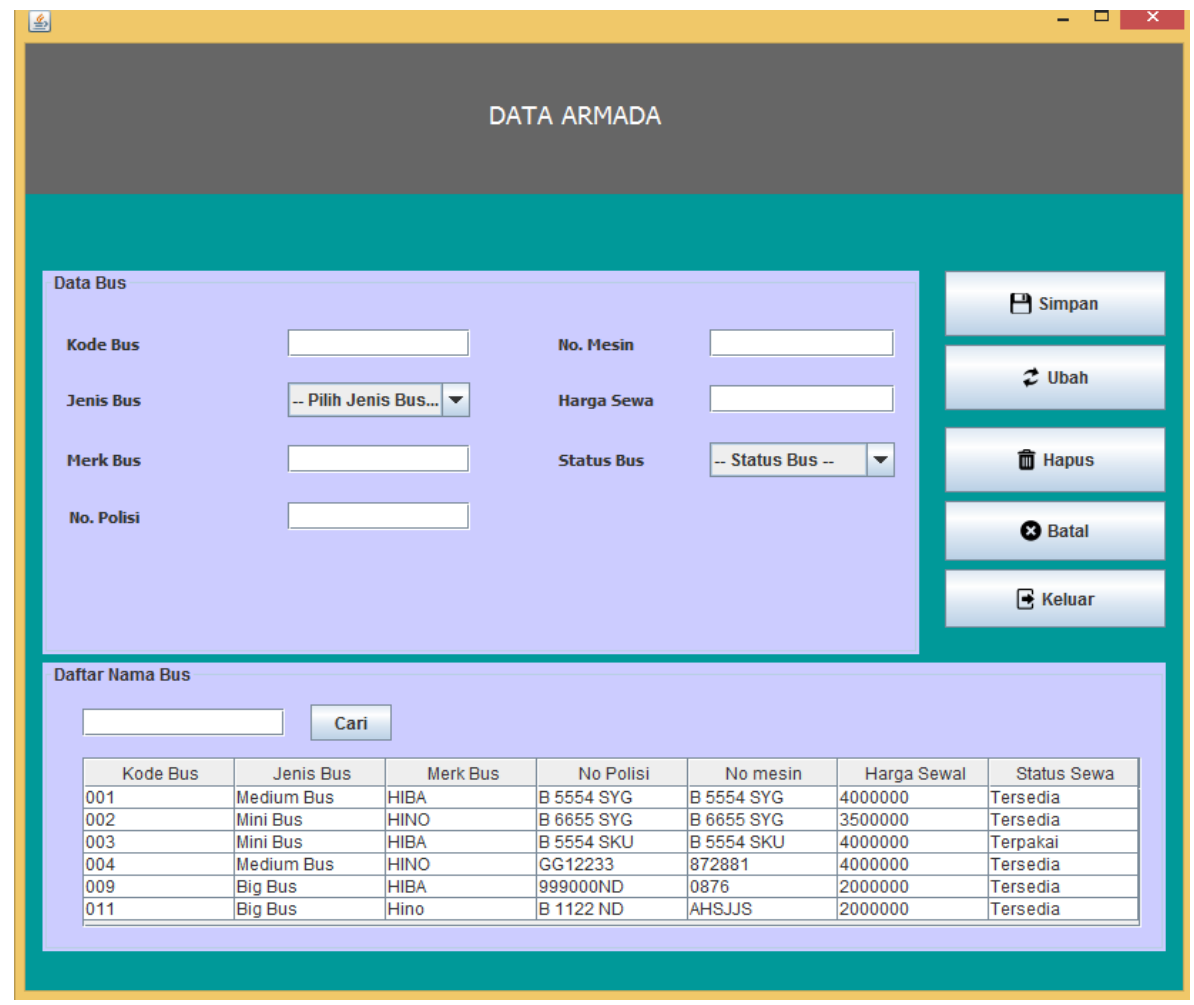

Gambar 7. Tampilan Format Masukan Nama Bus

Form ini berisikan mengenai inputan data bus yang ingin digunakan, untuk memasukkan databus yang di gunakan, menyimpan data bus yang telah di input, mengubah data yang telah dipesan si pengguna bus, menghapus data yang telah dipesan pengguna dan pencarian data yang akan di cari oleh pengguna. Serta tombol kembali untuk kembali ke dalam tampilan menu utama. 


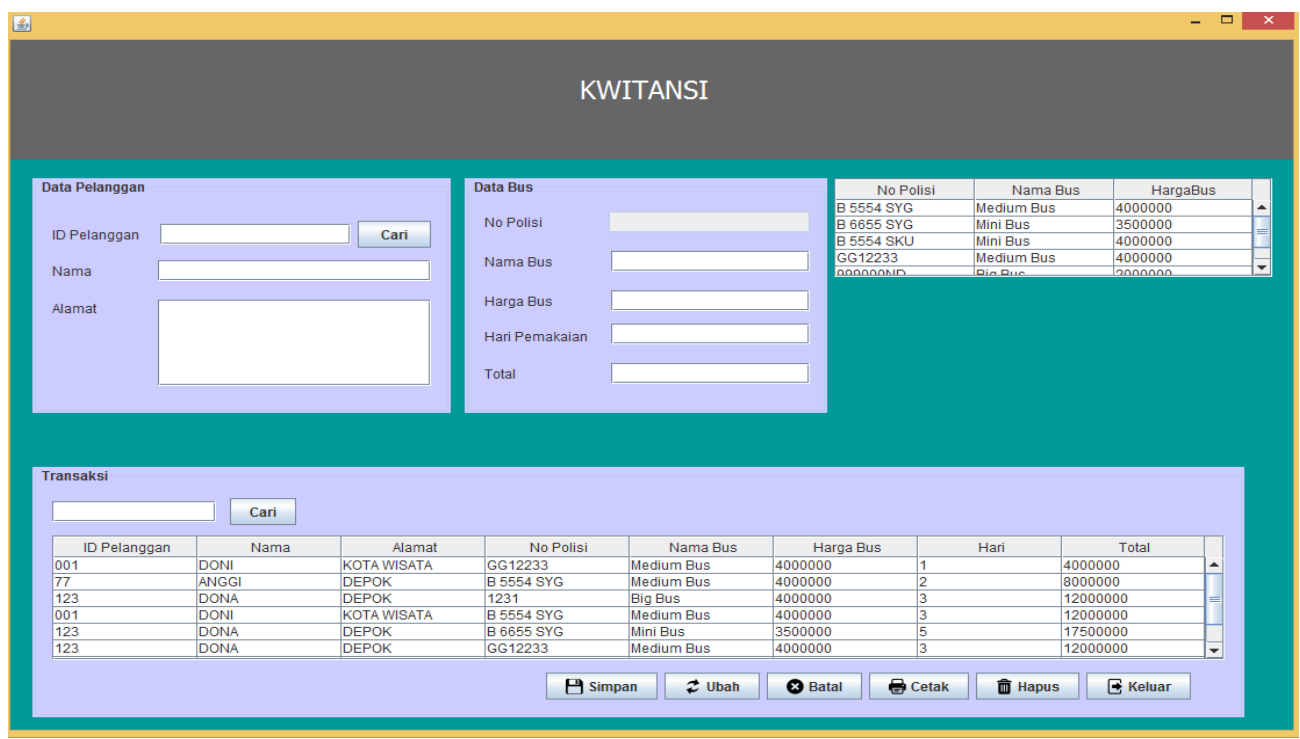

Gambar 8. Tampilan Proses Kwitansi

Tampilan proses pembayaran adalah sebagai menu laporan data tim yang telah di input dan dapat di cetak oleh petugas dan dijadikan laporan data pembayaran bulanan untuk di laporkan ke pimpinan PT Fitri Trans Abadi. Dan juga form ini juga digunakan untuk memasukkan data pembayaran yang sudah dilakukan oleh penyewa ke admin, dan admin dapat memberikan bukti pembayaran.

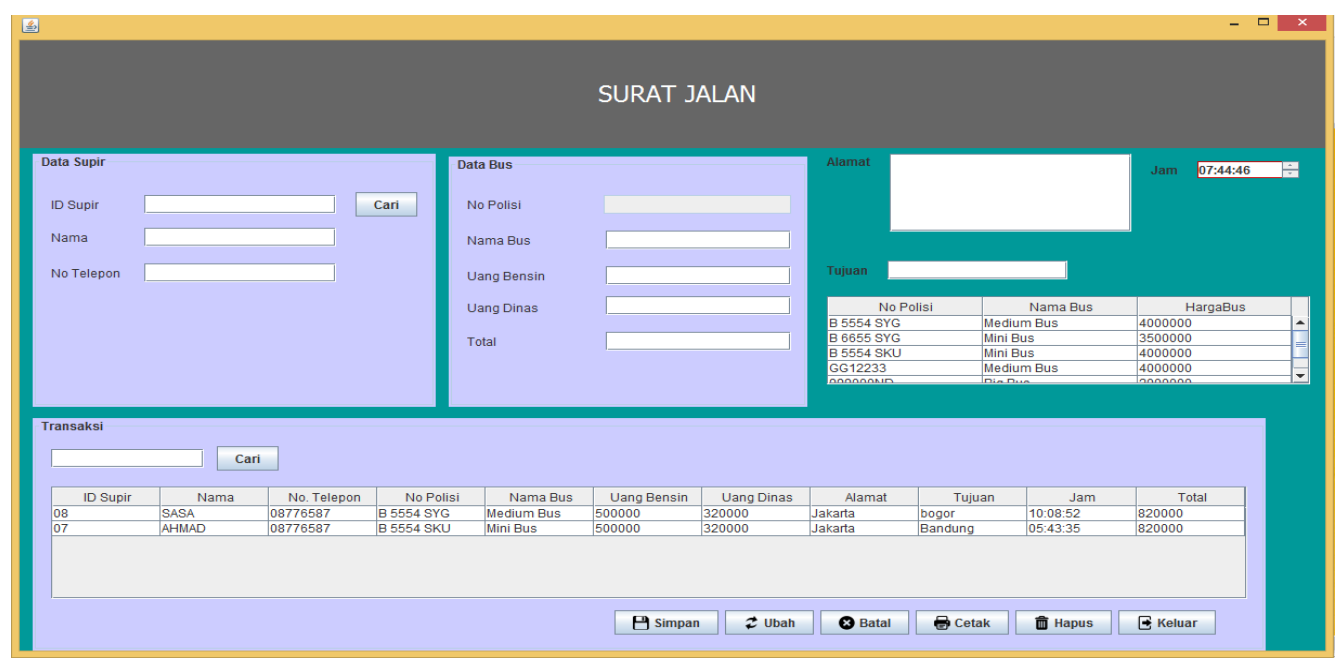

Gambar 9. Tampilan Proses Perjalanan

Tampilan surat perjalanan adalah tampilan form masukan perjalanan yang berfungsi memasukkan atau menambahkan data perjalanan, mengubah data perjalanan, dan menghaspus data perjalanan. Data perjalanan akan dicetak dan diberikan kepada pengemudi dalam bentuk surat perjalanan. Yang dimana surat perjalanan itu beisikan, nama penyewa, alamat penyewa, jenis bus yang disewa, alamat penjemputan, jam penjemputan, uang bbm untuk pengisian bbm bus dalam melakukan perjalanan, serta uang dinas untuk supir dan kenek, semua total perjalanan sudah tercantum dalam surat perjalanan (SPJ). 


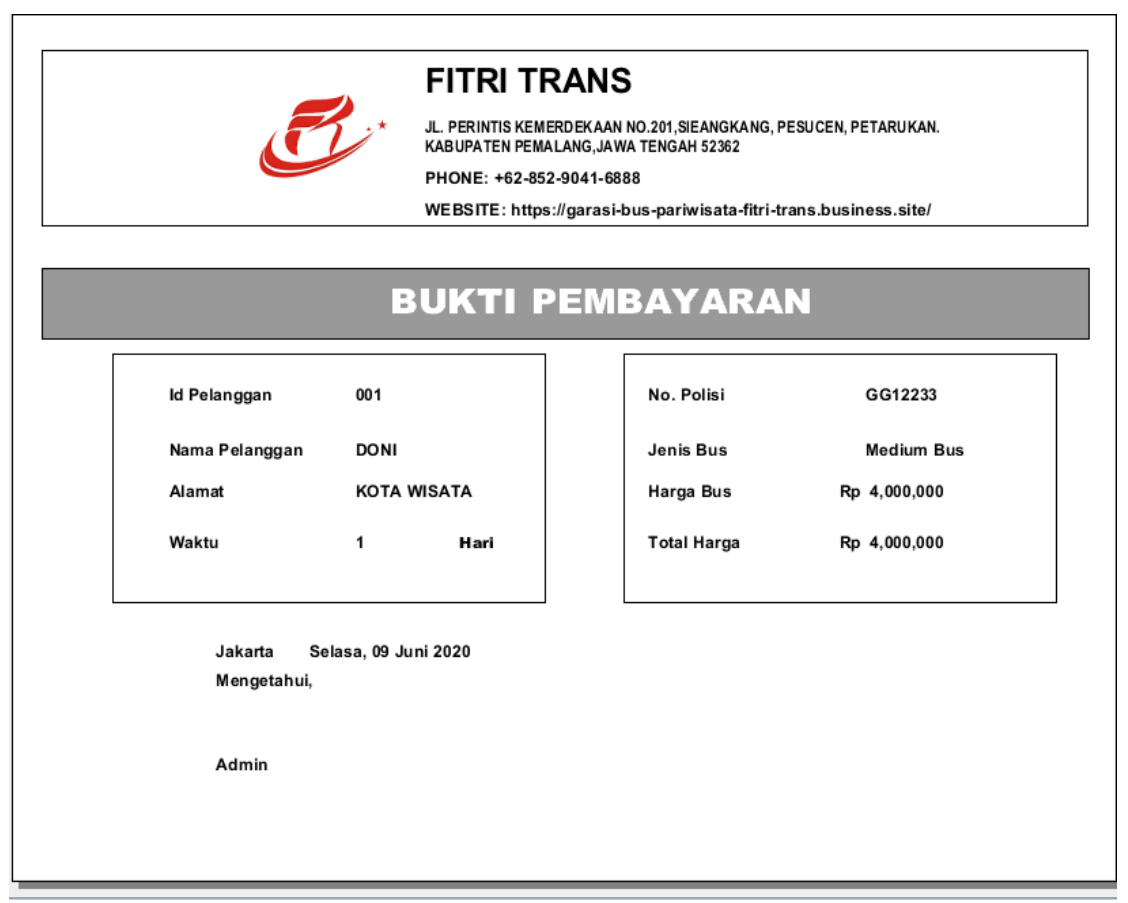

Gambar 10. Tampilan Bukti Pembayaran

Tampilan keluaran nota bukti pembayaran berisikan informasi pembayaran pemesanan unit kendaraan, nama pelanggan, alamat penyewa, waktu pemakaian, jenis bus, dan harga bus yang dibuat oleh admin dan sesuai dengan pemesanan penyewa. Laporan ini dapat dicetak, dan menjadi Bukti Pembayaran pemesanan unit setiap melakukan transaksi.

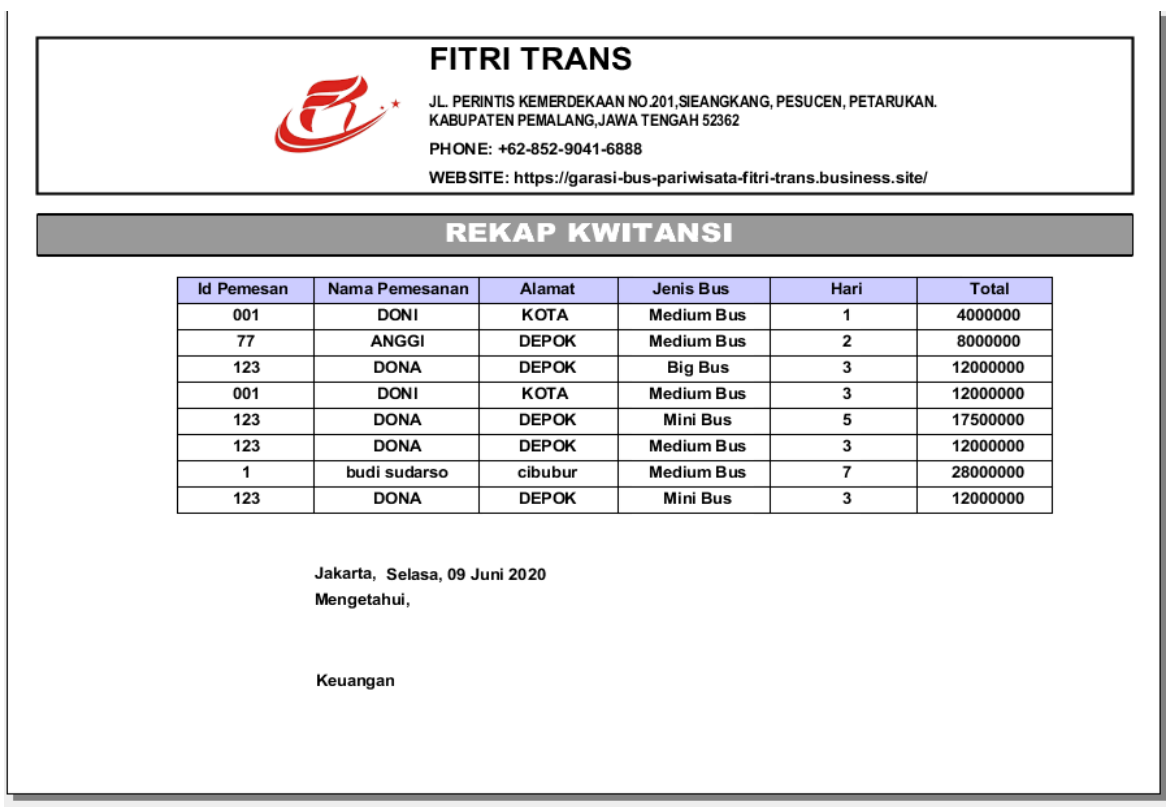

Gambar 11. Tampilan Rekapan Bukti Pembayaran 
Tampilan keluaran laporan bulanan kwitansi berisikan informasi laporan keuangan atau yang diambil dari bukti pembayaran sewa bus dari keuangan ke manager dalam waktu satu minggu maupun bulanan, laporan ini dapat dicetak. Laporan ini juga dapat digunakan sebagai database atau data yang digunakan sebagai laporan keuangan untuk mengetahui progress uang masuk atau laba rugi, yang tepat, cepat dan efisien.

\section{KESIMPULAN}

1. Sistem administrasi pemesanan tiket bus pariwisata yang sedang berjalan pada PT Fitri Trans Abadi masih dilakukan secara manual dan belum efektif dalam menangani administrasi pemesanan unit kendaraan dan masalah yang terjadi pada sistem tersebut.

2. Perancangan sistem administrasi pemesanan tiket bus pariwisata berbasis java pada PT Fitri Trans Abadi berhasil dibuat dengan menggunakan bahasa pemrograman java dan Mysql sebagai database. Yang diharapkan dalam diaplikasikan sesuai dengan fungsinya.

3. Perancangan sistem administrasi pemesanan tiket bus pariwisata pada PT Fitri Trans Abadi menjadikan operasional perusahaan lebih efektif, cepat, dan efisien dalam pengolahan datanya. Sistem administrasi yang peneliti buat hanya sebagai penunjang proses operasional untuk mengefisienkan waktu dan keakuratan data setidaknya dapat mambantu petugas dalam mengelola data pemesanan unit kendaraan.

\section{REFERENASI}

[1] S. Rizky, Konsep Dasar Rekayasa Perangkat Lunak. Jakarta: Prestasi, 2011.

[2] D. Darmawan and K. Nur Fauzi, Sistem Informasi Manajemen. PT Remaja Rosdakarya, 2013.

[3] Hanafi, "Pengaruh Biaya Pemasaran Terhadap Laba Pada PT. Prima Karya Manunggal Kabupaten Pangkep," J. Capacit. STIE AMKOP, 2017.

[4] T. Sutabri, Analisis Sistem Informasi. Yogyakarta: Andi Yogyakarta, 2012.

[5] A.-B. Bin Ladjamudin, Analisis dan Desain Sistem Informasi. Yogyakarta: Graha Ilmu, 2013. 